\title{
Strategi Pemasaran Online Pada Masa Pandemi Covid-19 Dalam Penerimaan Peserta Didik di SMK Al Hafidz Leuwiliang
}

\author{
Ilma Rahima. Dedi Junaedi, Evinovita \\ IAI Nasional Laa Roiba Bogor \\ ilmarahima@gmail.com,dedijunaedi@laaroiba.ac.id, evinovita@laaroiba.ac.id
}

\begin{abstract}
This study is intended to answer the following problems: 1) What is the online marketing strategy during the COVID-19 pandemic in accepting students at Al Hafidz Leuwiliang Vocational School? 2) What is the influence of the Al Hafidz Leuwiliang Vocational High School Online Marketing Strategy in accepting students during the covid 19 pandemic? These problems were discussed through research conducted at SMK Al HAfidz Leuwiliang where this madrasa was used as a source of data information to obtain portraits, descriptions, answers and results of marketing management strategies in order to increase student acceptance. In this case the data obtained by means of interviews, observation and documentation. All data will be analyzed descriptively, namely by pouring the results into sentences that are arranged in such a way that they can be neatly arranged sentences. The results of the study show that: 1) In the online marketing strategy at SMK Al Hafidz Leuwiliang implemented by every element in the school, this is because the marketing strategy planning implemented will be able to run more effectively and maximally. SMK Al Hafidz also uses three stages of online marketing strategy, namely: Segmentation; Namely consumer actions about the needs and wants both in the present and in the future, Targeting; namely positive targeting in determining which areas will become customers of Al Hafidz Vocational School. Three villages are prioritized, namely Karacak, Karyasari and Cibitung villages, as well as Positioning; namely about how to establish a position to gain competitive advantage between educational institutions in Leuwiliang District. 2) The implementation of online marketing strategies does not have much effect on student acceptance. Because offline marketing still needs to be needed by the customer (prospective students).
\end{abstract}

\section{Keywords: Online Marketing, Strategy, Covid 19 Pandemic}

\begin{abstract}
ABSTRAK
Penelitian ini dimaksudkan untuk menjawab permasalahan: 1) Bagaimana strategi pemasaran online pada masa pandemi covid 19 dalam penerimaan peserta didik di SMK Al Hafidz Leuwiliang? 2) Apa Pengaruh Strategi Pemasaran Online SMK Al Hafidz Leuwiliang dalam penerimaan peserta didik di masa pandemi covid 19? Permasalahan tersebut dibahas melalui penelitian yang dilaksanakan di SMK Al HAfidz Leuwiliang yang mana madrasah ini dijadikan sebagai sumber informasi data untuk mendapatkan potret, gambaran, jawaban dan hasil dari strategi manajemen pemasaran dalam rangka meningkatkan penerimaan peserta didik. Dalam hal ini data diperoleh dengan cara, wawancara, observasi dan dokumentasi. Semua data nanti akan dianalisis deskriptif yaitu dengan menuangkan hasil ke dalam kalimatkalimat yang disusun sedemikian rupa sehingga dapat menjadi kalimat yang tersusun dengan rapi. Hasil penelitan menunjukkan bahwa: 1) Dalam strategi pemasaran online di SMK Al Hafidz Leuwiliang dilaksanakan oleh setiap elemen di sekolah, hal ini dikarenakan agar perencanaan strategi pemasaran yang dilaksanakan akan dapat berjalan lebih efektif dan maksimal. SMK Al Hafidz juga mengunakan tiga tahapan strategi pemasaran online yaitu : Segmentation; Yaitu tindakan konsumen tentang kebutuhan serta keinginan baik dimasa
\end{abstract}




\section{VISA: Journal of Visions and Ideas \\ Vol 1 No 2 (2021) 78-100 E-ISSN 2809-2058 P-ISSN 2809-2643 \\ DOI: $47467 / v i s a . v 1 i 2.758$}

sekarang maupun dimasa yang akan datang, Targeting ; yaitu pentargetan secara positif dalam menentukan daerah mana yang akan menjadi pelanggan SMK Al Hafidz . Di Prioritaskan tiga desa, yaitu desan Karacak, Karyasari dan Cibitung, dan juga Positioning; yaitu tentang bagaimana menetapkan posisi untuk memperoleh keunggulan bersaing antar lembaga pendidikan yang ada di Kecamatan Leuwiliang. 2) Implementasi dari strategi pemasaran online tidak terlalu berpengaruh terhadap penerimaan peserta didik. Karena pemasaran secara offline pun masih perlu dibutuhkan oleh pihak pelanggan (calon peserta didik).

\section{Kata Kunci: Pemasaran Online, Strategi, Pandemi Covid 19}

\section{PENDAHULUAN}

Suatu lembaga pendidikan dapat berjalan jika terdapat komponen peserta didik, guru, kurikulum, sarana prasarana dan pengelola (Fitriani dan Arief : 2017). Komponen komponen ini saling berhubungan satu sama lain. Setiap sekolah akan membuka pendaftaran peserta didik baru untuk berlangsungnya pendidikan dalam sekolah tersebut. Untuk mendapatkan peserta didik, setiap lembaga pendidikan akan melakukan penerimaan pesera didik setiap tahunnya. Sekolah yang ingin mendapatkan peserta didik baru dan dapat bersaing dengan sekolah lain harus melakukan beberapa cara, salah satunya dengan membuat strategi pemasaran.

Setiap memasuki awal tahun, pasti setiap sekolah yang ada di Indonesia melakukan rekrutmen peserta didik baru atau telah kita kenal dengan istilah PPDB (Penerimaan Peserta Didik Baru) . Ketika strategi promosi yang dilakukan dipersiapkan dan dilakukan denga baik, tentu akan berimbas pada melonjaknya jumlah peserta didik yang mendaftar kepada sekolah tersebut. Begitupun sebaliknya, maka peserta didik yang mendaftar akan tidak maksimal atau bahkan bisa jadi tidak ada peserta didik sama sekali.

Pemasaran itu sendiri kini bisa dibedakan menjadi dua bagian, yaitu pemasaran secara online dan offline. Pemasaran online itu sendiri, berarti memasarkan suatu produk atau jasa melalui jaringan internet. Internet telah menjadi media yang terus berkembang fungsinya; tidak hanya sebagai media informasi saja, tetapi bisa juga sebagai media pemasaran.

Data dari internet World Stats menunjukkan sepanjang periode tahun 2000 2012, pertumbuhan pengguna internet diseluruh dunia mencapai dengan 566\%, dengan Asia sebagai penyumbang terbesar sebanyak 44,8\% dari total pengguna internet di dunia. Sementara itu, Indonesia menempati peringkat keempat di Asia dengan total pengguna internet sebanyak 55 juta. Pengguna internet yang begitu banyak dan perkembangan yang begitu pesat menjadikan peningkatan infrastruktur jaringan internet di Indonesia, memicu pertumbuhan progresif. Khususnya pada sistem penjualan online atau sering kita sebut dengan pemasaran online. 


\section{VISA: Journal of Visions and Ideas \\ Vol 1 No 2 (2021) 78-100 E-ISSN 2809-2058 P-ISSN 2809-2643 \\ DOI: 47467/visa.v1i2.758}

Sifat pemasaran online yang sangat dinamis dan berubah ubah begitu cepat, membutuhkan reaksi dan lagkah yang tepat agar sebuah produk maupun jasa dapat bertahan dan memenangkan persaingan. Sistem pemasaran online juga lebih mudah untuk dilakukan dan tidak begitu memerlukan biaya yang besar diawal pengoprasiannya. Hanya membutuhkan koneksi internet yang bagus dan Sumber daya manusia yang mumpuni untuk membangun pemasaran online tersebut.

Pemasaran online itu sendiri selain menggunakan platform pribadi sebuah instansi/ perusahaan seperti website, juga menggunakan platform sosial media dalam memasarkan produk produk dan jasanya. Salah satu platform sosial yang popular dan digandrungi anak milenial adalah whatsapp, Instagram , juga facebook. Menurut data dari situs Socialbakers, pengguna facebook di Indonesia menempati peringkat keempat di dunia dengan jumlah pengguna mencapai 51.515 .480 orang.

Penggunaan istilah pemasaran saat ini juga sudah sangat berkembang di semua sektor kegiatan kita. Jadi, dalam hal ini pemasaran ada juga yang dinamakan pemasaran pendidikan. Pemasaran pendidikan dapat diartikan sebagai proses transaksional untuk meningkatkan suatu harapan, keinginan dan kebutuhan calon konsumen ( peserta didik ), sehingga calon konsumen tertarik dan berminat pada produk yang ditawarkan dengan mengeluarkan imbalan yang telah disepakati.

Pemasaran juga merupakan salah satu ilmu ekonomi yang telah lama berkembang, dan sampai pada saat sekarang ini pemasaran sangat mempengaruhi keberhasilan suatu lembaga pendidikan untuk bisa bertahan di pangsa pasar. Oleh karena itu diperlukan strategi pemasaran yang dapat berpengaruh untuk mengahasilkan berhasil atau tidaknya suatu pemasaran memasarkan produknya. Dengan demikian strategi pemasaran harus dapat memberikan gambaran yang jelas dan terarah tentang apa yang dilakukan suatu perusahaan/ lembaga pendidikan dalam menggunakan setiap kesempatan atau paduan pada beberapa sasaran pasar.

Pemasaran online juga merupakan komponen dari usaha yang berfokus kepada pelaku pasar. Pemasaran online juga didefinisikan sebagai proses strategi dalam membuat, mendistribusikan, mempromosikan, dan memberikan harga serta fasilitas , pelayanan yang baik kepada target pasar melalui dunia digital atau internet.

Maka dari itu, tentu diperlukan strategi strategi dalam pemasaran online dalam menjalankan suatu usaha pada sebuah instansi/ perusahaan. Kotler dan Amstrong ( 2012 : 27 ) dalam bukunya yang berjudul yang berjudul "Prinsip prinsip Pemasaran" Strategi pemasaran juga merupakan pernyataan mengenai bagaimana suatu merek dapat memenuhi kebutuhan dan dapat memuaskan konsumen, begitupun pemasaran dalam bidang jasa. Bastion Swasta (2008 : 32) dalam bukunya yang berjudul "Manajemen Pemasaran Materi" , beberapa strategi pemasaran diterapkan akan mampu menembus pasar, mengembangkan pasar, mengembangkan produk, diversifikasi , pemfokusan pada pasar dan biaya yang murah. 


\section{VISA: Journal of Visions and Ideas \\ Vol 1 No 2 (2021) 78-100 E-ISSN 2809-2058 P-ISSN 2809-2643 DOI: 47467/visa.v1i2.758}

Strategi pemasaran juga merupakan bagian dari aktivitas pemasaran. Dalam Islam ketika memasarkan produk ada aturan-aturan yang harus dipenuhi baik itu dalam hal produk, konteks harga, distribusi, maupun dalam konteks promosi. Spiritual adalah strategi yang paling tepat dan paling unggul dan strategi ini bisa memayungi berbagai macam strategi lainnya. Seperti dalam hadits Rasulullah SAW, yang arrtinya : Rifa'ah bin Rafi' RA, Sesungguhnya Nabi Muhammad SAW, pernah ditanya : "apa pekerjaan yang paling utama atau naik?", Rasulullah menjawab, "Pekerjaan seorang laki-laki dengan tangannya dan setiap jual beli yang baik." (HR AlBazzar dan dibenarkan al-Hakim). Inti dari spiritual marketing ini adalah kejujuran yang dilandasi dengan keyakinan akan kebesaran Allah SWT, yang akan mengawasi setiap perbuatan manusia.

Dewasa ini telah kita ketahui wabah covid 19 berpotensi mengubah tatanan ekonomi dunia yang ditandai dengan berubahnya peta perdagangan dunia, selain mengakibatkan mandegnya berbagai sek tor. Corona Virus Disease 2019 (Covid 19) telah diyatakan oleh WHO sebagai pandemi dan Pemerintah Indonesia berdasarkan Keputusan Presiden Nomor 11 Tahun 2020 tentang Penetapan Kedaruratan Kesehatan Masyarakat Covid 19, telah menyatakan covid 19 sebagai kedaruratan kesehatan masyarakat yang wajib dilakukan upaya penanggulangan, serta menyebabkan proses kegiatan belajar mengajar peserta didik dilakukan di rumah dengan sistem online / daring. Begitupun proses pemasaran pada suatu lembaga pendidikan tersebut, sedikit banyak berubah menjadi pemasaran online.

Menurut laporan “Tinjauan Big Data Terhadap Dampak Covid-19 2020” yang disusun oleh Badan Pusat Statistik ( BPS ) , pemasaran online pada masa pandemik ini malah melonjak tajam bila dibandingkan dengan masa saat sebelum terjadinya wabah covid. Pada bulan Maret 2020, pemasaran online yang berupa produk melonjak sebanyak 320\% dari total pemasaran online awal tahun, sebelum terjadinya wabah covid-19. Lonjakan semakin tajam terjadi pada April 2020. Tercatat meningkat $480 \%$ dari januari 2020. Jika dirincikan pada bulan Maret 2020, penjualan tertinggi ada pada makanan dan minuman, yaitu meningkat sebanyak $570 \%$ dari penjualan pada Januri 2020. Penjualan terendah adalah produk olahraga yang hanya meningkat 170\% dari penjualan Januari 2020.

Selain pada makanan dan minuman, beberapa penjualan yang meningkat juga terjadi pada alat kesehatan, peralatan komunikasi, kosmetik, perlengkapan rumah tangga, peralatan pendidikan serta sandang.

Sebagaimana kita ketahui bahwa produk atau jasa suatu lembaga pendidikan tidak mungkin mencari sendiri konsumen ataupun peminatnya. Oleh karena itu, produsen dalam kegiatan pemasaran produk atau jasa harus membutuhkan konsumen mengenai produk atau jasa yang dihasilkannya. Dengan demikian, strategi pemasaran online harus dapat memberikan gambaran yang jelas dan terarah tentang 


\section{VISA: Journal of Visions and Ideas \\ Vol 1 No 2 (2021) 78-100 E-ISSN 2809-2058 P-ISSN 2809-2643 \\ D0I: 47467/visa.v1i2.758}

apa yang dilakukan oleh perusahaan/ lembaga pendidikan dalam menggunakan setiap kesempatan pada beberapa sasaran pasar.

Menurut Hadi Aziz Pratama dalam artikel yang ditulis tentang "Strategi Promosi Sekolah di Era Pandemi”, cara untuk memaksimalkan strategi promosi agar peserta didik yang mendaftar akan memenuhi kuota kelas yang beliau singkat menjadi KPK (Kurikulum Berdampak, Potongan harga dan Kanal Promosi).

SMK Al Hafidz Leuwiliang adalah salah satu lembaga pendidikan swasta yang berbasis kejuruan dan berada di Desa karyasari, Leuwiliang serta menjadi pilihan peneliti untuk dikaji strategi pemasaran online di masa covid 19 ini.

Berdasarkan hal diatas, peneliti tertarik untuk melakukan penelitian dengan judul "Strategi Pemasaran Online Pada Masa Pandemi Covid 19 dalam Penerimaan Peserta Didik di SMK Al Hafidz Leuwiliang".

\section{METODOLOGI PENELITIAN}

Metode penelitian yang digunakan dalam penelitian ini adalah penelitian deskriptif kualitatif. Menurut Sugiyono (2019), metode penelitian kualitatif adalah metode penelitian yang berlandaskan pada filsafat postpositivisme, digunakan untuk meneliti pada kondisi obyek yang alamiah, (sebagai lawannya adalah eksperimen) dimana peneliti adalah sebagai instrumen kunci, teknik pengambilan data dilakukan secara triangulasi (gabungan), analisis data bersifat induktif/kualitatif, dan hasil penelitian kualitatif lebih menekankan makna daripada generalisasi.

Penelitian kualitatif berusaha untuk menemukan dan menggambarkan secara naratif kegiatan yang dilakukan dan dampak dari tindakan yang dilakukan terhadap kehidupan mereka (Anggito, 2018).

Tujuan utama penelitian deskriptif kualitatif adalah untuk mendeskripsikan atau menggambarkan dan mengungkap berbagai situasi-situasi yang sangat kompleks, juga memberikan saran-saran bagi penelitian lebih lanjut.

\section{Tempat dan Waktu Penelitian}

Penelitian ini dilakukan di SMK Al Hafidz yang beralamat di Jalan Moch Noor Kp. Neglasari RT 002/002 Desa Karyasari Kec. Leuwiliang-Bogor, penulis memilih SMK Al Hafidz sebagai tempat penelitian karena SMK Al Hafidz ini merupakan salah satu sekolah yang melaksanaka pemasaran online pada masa pandemi covid ini. Penelitian ini dilaksanakan pada bulan Juni- Juli 2021.

\section{Variabel Penelitian}

Penelitian ini menggunakan satu variabel yaitu Strategi Pemasaran Online yang terdiri dari : Segmentasi Pasar, Targetting, Marketing Possitioning, Marketing Mix Strategy, Timing Strategy 


\section{VISA: Journal of Visions and Ideas \\ Vol 1 No 2 (2021) 78-100 E-ISSN 2809-2058 P-ISSN 2809-2643 \\ DOI: $47467 /$ visa.v1i2.758}

\section{Populasi dan Sampel Penelitian}

Populasi diartikan sebagai wilayah generalisasi yang terdiri atas : obyek/subyek yang mempunyai kualitas dan karakteristik tertentu yang ditetapkan oleh peneliti untuk dipelajari dan kemudian ditarik kesimpulannya. Sedangkan sampel adalah sebagian dari populasi itu.

Sampel dalam penelitian ini adalah Kepala Sekolah SMK Al Hafidz Leuwiliang, Waka ke peserta didikan, dan Guru yang terkait dalam PPDB . Untuk menggali informasi, peneliti langsung mengadakan tanya jawab dibantu dengan daftar pertanyaan sebagai pedoman wawancara untuk memudahkan dalam penggalian data dan informasi yang diperlukan.

\section{Instrumen Penelitian}

Instrumen penelitian adalah pedoman tertulis tentang wawancara, atau pengamatan, atau daftar pertanyaan, yang dipersiapkan untuk mendapatkan Informasi dari responden (Gulo, 2002).

Dalam penelitian kualitatif (karena tidak melakukan pengukuran, tetapi eksplorasi untuk menemukan), maka yang menjadi instrumen atau alat penelitian adalah peneliti itu sendiri. Peneliti kualitatif sebagai human instrument berfungsi menetapkan fokus penelitian, memilih informan sebagai sumber data, melakukan pengumpulan data, menilai kualitas data, analisis data, menafsirkan data, dan membuat kesimpulan atas temuannya.

Dalam penelitian ini menggunakan dua pedoman instrumen penelitian antara lain :

1) Pedoman Wawancara

2) Dokumen

Dokumen yang diperlukan dokumen adalah profil SMK Al Hafidz Leuwiliang mencakup visi, misi, jumlah peserta didik baru tahun pelajaran 2020 dan 2021, daftar peserta didik, dan jumlah guru SMK Al Hafidz Leuwiliang.

\subsection{Teknik Pengumpulan Data}

Teknik pengumpulan data merupakan langkah yang paling utama dalam penelitian, karena tujuan utama dari penelitian adalah mendapatkan data.

Dalam penelitian ini digunakan teknik pengumpulan data sebagai berikut:

1) Observasi

Observasi merupakan suatu proses yang kompleks, suatu proses yang tersusun dari pelbagai proses biologis dan psikologis. Dua diantara yang terpenting adalah proses-proses pengamatan dan ingatan. Teknik pengumpulan data dengan observasi digunakan bila penelitian berkenaan dengan perilaku manusia, proses kerja, gejala-gejala alam dan bila responden yang diamati tidak terlalu besar(Sugiyono, 2019).

Pengamatan observasi adalah metode pengumpulan data di mana peneliti atau kolaboratornya mencatat informasi sebagaimana yang mereka saksikan selama penelitian. Penyaksian terhadap peristiwa- 


\section{VISA: Journal of Visions and Ideas}

\section{Vol 1 No 2 (2021) 78-100 E-ISSN 2809-2058 P-ISSN 2809-2643 DOI: 47467/visa.v1i2.758}

peristiwa itu bisa dengan melihat, mendengarkan, merasakan, yang kemudian dicatat seobjektif mungkin.

Dalam penelitian ini observasi dilakukan untuk mengetahui keadaan umum SMK Al Hafidz Leuwiliang.

2) Wawancara / interview

Wawancara adalah bentuk komunikasi langsung antara peneliti dan responden. Komunikasi berlangsung dalam bentuk tanya jawab dalam hubungan tatap muka, sehingga gerak dan mimik responden merupakan bola media yang melengkapi kata-kata secara verbal(Gulo, 2002).

Wawancara digunakan sebagai teknik pengumpulan data apabila peneliti ingin melakukan studi pendahuluan untuk menemukan permasalahan yang harus diteliti, dan juga apabila peneliti ingin mengetahui hal-hal dari responden yang lebih mendalam dan jumlah respondennya kecil/sedikit. Esterberg (2002) mengemukakan beberapa macam wawancara, yaitu wawancara terstruktur, semi terstruktur, dan tidak terstruktur.

Dalam penelitian ini wawancara yang digunakan yaitu jenis wawancara terstruktur. Wawancara terstruktur digunakan sebagai teknik pengumpulan data bila peneliti atau pengumpul data telah mengetahui dengan pasti informasi apa yang akan diperoleh. Oleh karena itu, dalam melakukan wawancara pengumpul data telah menyiapkan instrumen penelitian berupa pertanyaan-pertanyaan tertulis sebagai pedoman wawancara. Dipilihnya wawancara terstruktur dalam penelitian ini untuk menghindari hasil yang didapat dari penelitian tidak keluar jalur dan lebih fokus kepada permasalahan strategi pemasaran online dalam penerimaan peserta didik di SMK Al Hafidz Leuwiliang.

Wawancara dilakukan kepada Kepala Sekolah SMK Al Hafidz Leuwiliang, Humas SMK Al Hafidz Leuwiliang, dan Guru. Tujuan dari wawancara ini untuk mengetahui secara riil mengenai Strategi Pemasaran Online di SMK Al Hafidz Leuwiliang.

3) Dokumentasi

Dokumen merupakan catatan peristiwa yang sudah berlalu. Dokumen bisa berbentuk tulisan, gambar, atau karya-karya monumental dari seseorang. Studi dokumen merupakan pelengkap dari penggunaan metode observasi dan wawancara dalam penelitian kualitatif.

Penggunaan dokumentasi dalam penelitian ini untuk mengetahui secara objektif tentang strategi pemasaran di SMK Al Hafidz. Dokumentasi tersebut terdiri dari :

a. Data mengenai profil SMK Al Hafidz Leuwiliang mencakup visi, misi, jumlah peserta didik, daftar peserta didik, dan jumlah guru SMK Al Hafidz Leuwiliang. 


\section{VISA: Journal of Visions and Ideas \\ Vol 1 No 2 (2021) 78-100 E-ISSN 2809-2058 P-ISSN 2809-2643 DOI: $47467 /$ visa.v1i2.758}

b. Data peserta didik SMK Al Hafid pada tahun ajaran 2020-2021 saat pandemi covid terjadi dan dokumen lainnya yang relevan serta dokumen dokumen yang telah disusun berbagai pihak tentang obyek yang diteliti.

\section{Teknik Analisis Data}

Analisis data adalah proses mencari dan menyusun secara sistematis data yang diperoleh dari hasil wawancara, catatan lapangan, dan dokumentasi dengan cara mengorganisasikan data kedalam kategori, menjabarkan kedalam unit-unit, melakukan sintesa, menyusun kedalam pola, memilih mana yang penting dan yang akan dipelajari dari membuat kesimpulan sehingga dapat mudah dipahami dan temuannya dapat di informasikan kepada orang lain.

Penelitian ini menggunakan teknis analisis data model Miles and Huberman. Miles and Huberman mengemukakan bahwa aktivitas dalam analisis data kualitatif dilakukan secara interaktif dan berlangsung secara terus menerus sampai tuntas, sehingga datanya sudah jenuh. Aktivitas dalam analisis data, yaitu data reduction, data display, dan conclusion drawing / verification(Sugiyono, 2019).

\section{HASIL PENELITIAN DAN PEMBAHASAN}

\section{Gambaran Lokasi Penelitian}

SMK Al Hafidz didirikan berdasarkan potensi wilayah dan kebutuhan masyarakat Desa Karyasari Kecamatan Leuwiliang dan sekitarnya, atas prakarsa dari Ketua Yayasan Pendidikan Al Hafidz Bapak Drs. H. Sudirman, MM dan dukungan tokoh-tokoh masyarakat, dan izin Operasional dari Dinas Pendidikan Kabupaten Bogor ditetapkan di Cibinong pada tanggal 04 Juli 2013 (dimasa Kadis; Bpk Drs. Rustandi, M.Si), serta Keputusan Menteri Hukum dan Hak Asasi Manusia Republik Indonesia yang ditetapkan di Jakarta Pada tanggal 01 Agustus 2013 (dimasa Direktur Jenderal Administrasi Hukum Umum; Bpk. Dr. Aidir Amin Daud, SH., MH).

Potensi wilayah dan kebutuhan masyarakat disekitar SMK Al Hafidz yaitu desa Karyasari, Karacak, Puraseda, Purasari dan Cibitung Wetan tidak semua peserta didik lulusan SMP/MTS berkesempatan untuk melanjutkan ke SMK/SLTA pada umumnya karena berbagai hal, antara lain faktor ekonomi keluarga, jarak tempuh yang terlalu jauh dan pilihan keahlian yang diinginkan dan digemari masyarakat belum tersedia yang akhirnya mereka memilih untuk tidak melanjutkan sekolah.

Dari latar belakang tersebut, SMK Al Hafidz ingin mewadahi mereka apa adanya, tidak merasa terbebani dengan biaya yang tinggi. Pada tahun 2013 SMK Al Hafidz Leuwiliang berdiri dan menyelenggarakan pendidikan mulai tahun pelajaran 2013/2014 dibawah naungan Kepala Sekolah Bpk. Luluk Waluyo Utomo, S.Pd, bertempat di Jl. Moh Noh Noor Km. 8 Kp. Hegarsari RT 04/01 Desa Karyasari Bogor 16640. Bidang Keahlian yang diselenggarakan adalah Bisnis dan Manajemen, dengan 


\section{VISA: Journal of Visions and Ideas \\ Vol 1 No 2 (2021) 78-100 E-ISSN 2809-2058 P-ISSN 2809-2643 \\ DOI: 47467/visa.v1i2.758}

Program Keahlian : Otomatisasi dan Tata Kelola Perkantoran (Pada angkatan pertama jumlah peserta didik 41 orang) dan Teknik Informasi dan Komunikasi dengan Program Keahlian Rekayasa Perangkat Lunak (Pada angkatan pertama jumlah peserta didik 25 orang) atau 2 rombongan belajar atau 2 kelas.

\section{Struktur Organisasi SMK Al Hafidz}

Gambar 4.1 Struktur Organisasi SMK Al Hafidz Leuwiliang

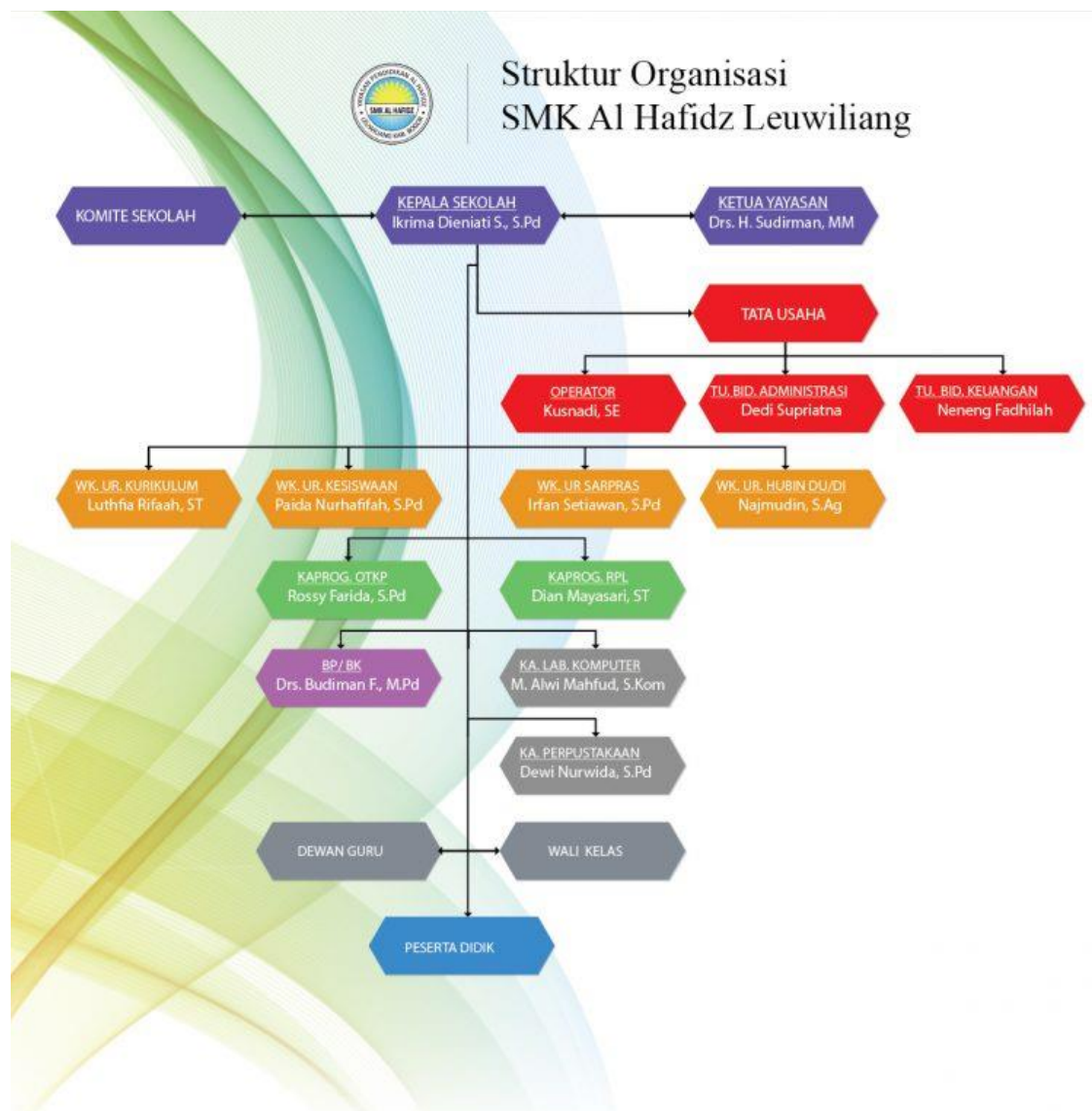

\section{Kegiatan Belajar Mengajar dan Ekstrakurikuler}

\section{Kegiatan Belajar Mengajar}

i. $\quad$ Kurikulum yang digunakan : K-13

ii. Durasi Jam Tatap Muka : 45 Menit/JTM

iii. Jam Belajar : Mulai Pukul 07:15-14:00 WIB

iv. Kegiatan Rutin Agama

Kegiatan rutin agama yang dilaksaakan oleh SMK Al Hafidz Leuwiliang diantaraya adalah : tadarus, pembinaan kerohanian Islam, muhadhoroh, hapal Al Ma'surat , Hapal Juz 30, Mabit, shalat berjama'ah, training motiasi, 


\section{VISA: Journal of Visions and Ideas}

\section{Vol 1 No 2 (2021) 78-100 E-ISSN 2809-2058 P-ISSN 2809-2643 DOI: 47467/visa.v1i2.758}

bakti sosial, pengajian keliling, manasik Haji- Umrah, qiraati Qur'an, tadabbur alam, Islamic coaching, parenting.

\section{a. Kegiatan Ekstrakurikuler}
i. Pramuka
ii. Futsal
iii. Rohis
iv. Paskibra
v. Islamic Technology Active Community
vi. Pencak Silat Tapak Suci
vii. Futsal

\section{Data Khusus SMK AL Hafidz Leuwiliang}

Data khusus yang diperoleh dari SMK Al Hafidz Leuwiliang adalah data mengenai data peserta didik tahun 2020 \& 2021 yang mendaftar saat terjadi pandemi covid-19.

Data dikelompokan menjadi dua komponen, yaitu strategi pemasaran online yang dilakukan oleh SMK Al Hafidz Leuwiliang pada masa pandemi covid dan pengaruh strategi pemasaran online pada masa pandemi covid ini . Data diperoleh dari wawancara, dokumentasi, dan observasi.

Selanjutnya, penelitian ini dilaksanakan selama kurang lebih 2 bulan mulai Juni 2021 sampai bulan Juli 2021. Penelitian ini dilakukan di SMK Al Hafidz Leuwiliang. Begitupun juga dengan fokus yang lain penelitian ini dilakukan diluar kantor, waktu kurang lebih 2 bulan ini mencakup pencarian narasumber yang berkompeten dalam kaitannya dengan strategi pemasaran online pada masa pandemi covid 19 ini dalam penerimaan peserta didik di SMK Al Hafidz Leuwiliang. Adapun narasumber yang dijadikan subjek penelitian dalam penelitian ini adalah, sebagai berikut:

Tabel 4.1 Identitas Informan

\begin{tabular}{|l|l|l|l|}
\hline No & Nama Narasumber & Jenis Kelamin & $\begin{array}{l}\text { Pekerjaan } \\
\text { Narasumber }\end{array}$ \\
\hline 1. & Ikrima Dieniati S, S.Pd & Perempuan & Kepala Sekolah \\
\hline 2. & Najmudin, S.Ag & Laki laki & Waka Ur HUBIN DU \\
\hline 3. & Andini Rahmawati & Perempuan & Peserta didik \\
\hline
\end{tabular}

Dengan demikian peneliti mendapat 3 narasumber yang akan dijadikan subjek penelitian. Narasumber penelitian diharapkan kedepannya mampu membantu memberikan pernyataan sesuai dengan topik peneltian guna mendapatkan data penelitian yang dibutuhkan oleh peneliti. 


\section{VISA: Journal of Visions and Ideas \\ Vol 1 No 2 (2021) 78-100 E-ISSN 2809-2058 P-ISSN 2809-2643 \\ DOI: 47467/visa.v1i2.758}

\section{Strategi Pemasaran Online pada masa Pandemi Covid 19 dalam Penerimaan Peserta Didik di SMK Al Hafidz Leuwiliang}

Strategi pemasaran merupakan langkah pertama yang dilaksanakan dalam mencapai tujuan. Tetapi, pada masa pandemi covid 19 ini strategi pemasaran yang lebih digencarkan yaitu dengan cara sistem pemasaran online. Di dalam strategi pemasaran online dibuat agar program program kerja dalam strategi pemasaran dapat terlaksana dengan baik. Adanya suatu strategi pemasaran yang telah disusun dengan baik menjadi dasar ketika program yang akan dicapai terdapat banyak masalah yang akan dihadapi. Maka dari itu perlunya strategi pemasaran online yang baik agar dapat meminimalisir kegagalan yang akan dihadapi.

Strategi Pemasaran Online menjadi salah satu lingkup penting didalam suatu lembaga/ perusahaan terlebih saat terjadi pandemi covid 19 ini yang mengharuskan hamper semuaa kegiata dilakukan secara sistem online guna meminimalisir jumlah orang yang tertular akan pandemi covid 19 ini, terutama pada suatu lembaga pendidikan. Strategi pemasaran online di suatu sekolah tetap harus berjalan walaupun sedang mengalami covid 19 ini untuk mendapatkan peserta didik dengan jumlah yang banyak dan menarik minat calon peserta didik. SMK Al Hafidz Leuwiliang yang terletak di Desa Karyasari, Kecamatan Leuwiliang, Kabupaten Bogor, memiliki perencanaan strategi pemasaran online untuk tetap memasarkan produk yang dihasilkan oleh lembaganya walaupun dalam pandemi covid 19 guna meningkatkan jumlah peserta didik setiap tahunnya. Hal ini seperti dengan yang diungkapkan oleh Bapak Najmudin selaku Waka Ur. Hubin SMK Al Hafidz Leuwiliang bahwa:

"Kami ( SMK Al hafidz Leuwiliang) harus jeli untuk melihat peluang pasar khususnya untuk mendapatkan peserta didik terlebih pada masa pandemi covid 19 ini. Hal yang kami lakukan, hampir sama dengan strategi pemasaran sebelum terjadinya pandemi covid 19 yaitu membuat perangkat pemasaran seperti merencanakan membentuk tim pelaksanaan PPDB, waktu, dan tempat, target yang dituju, dan tentunya media sosial untuk memasarkan dan mempromosikan SMK Al Hafidz Leuwiliang ini".

Dalam perencanaan strategi pemasaran Online di sekolah SMK Al Hafidz Leuwiliang, maka tetap disusun panitia PPDB yang terdiri dari wali kelas, dan PKM atau pimpinan SMK Al Hafidz Leuwiliang seperti waka kepeserta didikan, waka kurikulum, waka humas, dan waka sarpras, kemudian kepala sekolah membentuk perangkat pemasaran, akan tetapi yang dilakukan pertama kali adalah sosialisasi menggunaan sosial media seperti whatsapp, instagram, website dan brosur setelah itu dilakukan pembagian waktu dan tempat promosi.

Meskipun dalam keadaan pandemi, tetapi beberapa strategi pemasaran yang dilakukan oleh SMK Al Hafidz dilakukan secara offine juga. Dalam mempromosikan sekolah SMK Al HAfidz Leuwiliang yang pertama dilakukan adalah menentukan 


\section{VISA: Journal of Visions and Ideas \\ Vol 1 No 2 (2021) 78-100 E-ISSN 2809-2058 P-ISSN 2809-2643 \\ DOI: 47467/visa.v1i2.758}

waktu dan tempat, kapan dan dimana proses promosi dilakukan, apakah hanya di daerah sekolah saja atau di luar daerah sekolah tersebut. Karena tidak semua sekolah melakukan KBM secara offline pada masa pandemi covid 19 ini. Hal ini diperjelas kembali oleh Bapak Najmudin selaku Waka Ur. Hubin , yang mengatakan bahwa:

"Rencana waktu dan tempat promosi kami lakukan agar kami paham bentuk layanan pendidikan seperti apa yang sedang dibutuhkan oleh masyarakat khususnya di Desa Karyasari, ternyata setelah melakukan rapat bersama kepala sekolah kami menemukan fakta bahwa promosi harus dilakukan diluar sekolah juga".

Pada dasarnya setiap sekolah selalu membuka peluang untuk sekolah yang tingkatnya lebih atas untuk memasarkan/mempromosikan sekolahya. Tetapi, selama pandemi covid19 ini terjadi, tidak semua sekolah pembuka peluang itu. Hal ini seperti yang dikatakan oleh bapak Najmudin Waka Ur. Hubin bahwa :

"Setiap tahun kami melakukan sosialisasi ke setiap sekolah sekolah. Akan tetapi sewaktu pandemi covid 19 terjadi, ada yang menerima dan ada juga yang tidak (dibatasi). Dan sewaktu begitu, kita sama sama untuk saling mengerti saja"

Walaupun ditengah keadaan pandemi, strategi pemasaran tentu tetap dilakukan oleh SMK Al Hafidz, tetapi pada masa pandemi ini SMK Al Hafidz memasarkan sekolah lebih optimal melalui online. Hal ini seperti yang dipaparkan oleh Bapak Najmudin Waka Ur. Hubin bahwa :

"Perbedaan pemasaran dari tahun sebelumnya, kami lebih memasarkan sekolah secara lebih optimal teh. Karena untuk memasarkan suatu produk itu tahun ini kami harus memasarkan lebih optimal via semua sosial media. Mulai dari Instagram, facebook, website maupun via whatsapp. Tentu kami memprioritaskan pemasaran online terlebih dahulu pada pandemi covid 19 ini"

Sedangkan target yang di tuju ini semua jenjang peserta didik harus orangorang yang mampu, mampu dalam arti mereka mampu dalam hal biaya, tapi hal ini target yang dituju adalah peserta didik dari SMP/Mts manapun yang tidak memandang dari golongan atas, menengah, maupun bawah. Semuanya bisa bersekolah di . Selain target, waktu, dan tempat yang direncanakan Dalam menentukan tim pelaksana strategi pemasaran SMK Al Hafidz Leuwiliang penyusunan perencanaan dilakukan oleh kepala sekolah, guru, karyawan, pembina ekstra kurikuler, dalam arti semua pendidik harus mengikutsertakan dalam proses mempromosikan suatu sekolah, karena berhasil dan tidaknya sebuah promosi itu terdapat pada tim pelaksana. Tim pelaksana harus menggunakan media dalam mempromosikan sekolahnya.

Penggunaan media dalam hal untuk mempromosikan suatu sekolah kita harus melihat target dari SMK tersebut untuk menunjang proses keberhasilan dalam sebuah promosi. Tanpa adanya sebuah promosi maka sekolah tersebut tidak akan 


\section{VISA: Journal of Visions and Ideas \\ Vol 1 No 2 (2021) 78-100 E-ISSN 2809-2058 P-ISSN 2809-2643 \\ D0I: 47467/visa.v1i2.758}

dikenal di masyarakat. Banyak calon pseserta didik/ peserta didik yang bersekolah di SMK Al Hafidz selain mengetahui dari sosial media atau brosur yang ditempel dijalan, mereka juga menjadi lebih tertarik karena pemasaran yang dilakukan oleh SMK Al hafidz saat berpromosi atau memasarkan SMK Al Hafidz di sekolah mereka sebelumnya. Karena terlihat lebih mendalami aqidah dan akhlaknya juga lebih terlihat religius walaupun sekolah tersebut berbasis SMK. Hal ini dipaparkan oleh Andini Rahmawati selaku peserta didik baru 2020, mengatakan bahwa:

"Pertama saya berfikir melanjutkan sekolah di SMK AL Hafidz karena iut ikutan teman karena banyak teman yang bersekolah di sini. Tapi sewaktu pihak SMK Al Hafidz mempromosikan ke sekolah SMP kami dan menjelaskan tetang produk dan lainnya, saya semakin tertarik kepada SMK Al Hafidz karena lebih mengutamakan aqidah, akhlak, dan lebih mengutamakan keagamaan".

Walaupun dalam keadaan pandemic, pembuatan produk untuk memasarkan pemasaran pun tetap di buat oleh SMK Al Hafidz. Hal serupa juga dipertegas oleh Bapak Najmudin selaku Waka Ur HUBIN, mengatakan bahwa:

"Walaupun dalam keadaan pandemi, kami tetap melakukan strategi pemasaran melalui pembuatan brosur dan banner atau baliho yang kami tempel di tempat-tempat yang sering di kunjungi banyak orang seperti di jalan khusunya di Desa Karyasari, Karacak dan Puraseda".

SMK Al Hafidz Leuwiliang ini juga ini menentukan untuk biaya infaq atau SPP dibuat untuk semua kalangan dapat masuk ke SMK Al Hafidz ini, terlebih SMK Al Hafidz dikhususkan kepada masyarakat di kalangan bawah mengigat karena letaknya di pedesaan sehingga biaya SPP nya cukup terjangkau. Hal ini diperjelas oleh peserta didik juga melalui wawancara yang dilakukan peneliti, mengatakn bahwa:

"Biaya SPP di SMK Al Hafidz perbulannya cukup murah dan menurut saya standar yaitu 60rb perbulan di bandingkan degan sekolah lain ada yang mencapai 200rb perbulan teh".

Oleh karena itu, Suatu lembaga pendidikan harus memperhatikan biaya terutama untuk golongan menengah kebawah terlebih terletak di pendesaan. Untuk meningkatkan kemampuan peserta didik SMK Al Hafidz Leuwiliang ini juga dirancang untuk memudahkan pelanggan supaya wali murid mudah untuk mendaftarkan anaknya disini dan memudahkan peserta didik untuk sampai ke depan pintu gerbang dan mampu memberi kenyamanan dalam proses belajar mengajar serta dapat di jangkau oleh kendaraan umum.

Dalam rangka menciptakan dan mencari pelanggan atau konsumen, SMK Al Hafidz ini merencanakan alat yang digunakan untuk mempromosikan SMK Al Hafidz Leuwiliang tersebut, pada dasarnya tidak ada perbedaan yang berarti antara pemasaran offline dan online yaitu: dengan menggunakan media sosial, brosur, lewat 


\section{VISA: Journal of Visions and Ideas \\ Vol 1 No 2 (2021) 78-100 E-ISSN 2809-2058 P-ISSN 2809-2643 \\ DOI: 47467/visa.v1i2.758}

wali murid, teman, dari mulut ke mulut, spanduk dan pamflet. Karena dengan strategi pemasaran seperti itu sekolah tersebut di harapkan dapat dikenal dengan banyak orang, tidak hanya sekitar Desa Karyasari saja tapi luar Desa Karyasari juga. Hal ini senada diungkapkan oleh Ibu Ikrima selaku Kepala Sekolah SMK Al Hafidz Leuwiliang, mengatakan bahwa:

"Salah satu cara pemasaran yang dilakukan SMK Al Hafidz Leuwiliang terlebih di masa pandemi covid 19 adalah lebih menggencarkan promosi lewat online melalui media sosial juga tetap menggunakkan pembuatan brosur teh. Brosur berisi tentang jadwal pembelajaran, serta fasilitas yang kami miliki, program beasiswa dan pengenalan jurusan sekolah".

Berdasarkan hasil wawancara diatas, Promosi dalam suatu lembaga itu sangat penting karena untuk mempromosikan lembaga kepada masyarakat agar masyarakat mau menjadi konsumen tetap. Selain promosi penting digunakan dalam startegti pemasaran, kualitas pendidik juga harus diperhatikan. Untuk tenaga pendidik disini di harapkan sudah memenuhi kriteria seorang pendidik, diharapkan mampu memberikan contoh yang baik kepada peserta didik dan tenaga pendidik yang kurang profesional di ikut sertakan dalam LPG (lembaga pendidikan guru) serta mampu mengajarkan program-program unggulan yang dimiliki oleh SMK Al Hafidz tersebut. sebagai pendidik diharapkan bisa menjaga sikap dan berinteraksi baik dengan masyarakat sekitar.

Dalam hal fisik, SMK Al Hafidz Leuwiliang akan memberikan yang terbaik kepada peserta didik dan sebagai wujudnya lagi pada tahun 2016 rencananya akan di tambahnya lokal kelas dan tempatnya tidak jauh dari gedung yang pertama yang nantinya akan digunakan untuk penambahan kuota jumlah peserta didik tahun ajaran baru selanjutnya yang akan masuk di SMK Al Hafidz Leuwiliang.

Dari strategi strategi yang dibuat oleh kepala skolah dan pihak guru. Diharapkan semua yang telah di ajarkan dan diprogramkan dari sekolah ini bisa dilaksanakan dengan baik, dan SMK Al Hafidz Leuwiliang ini bisa membentuk sebuah karakter, dan membentuk kepribadian peserta didik sebagai ciri khas dari sekolah tersebut yang mendalami keagamaan sekaligus berbasis kejuruan.

1. Pengaruh strategi pemasaran online pada masa pandemi covid 19 dalam penerimaan peserta didik di SMK Al Hafidz Leuwiliang

Di dalam suatu strategi pemasaran, khususnya pemasaran online yang kini tengah lebih digencarkan oleh semua sekolah terutama SMK Al Hafidz Leuwiliang, tentu memiliki beberapa pengaruh. Dalam hal ini dapat dijelaskan bahwa pemasaran online tidak begitu berpengaruh terhadap penerimaan peserta didik baru, karena kebanyakan calon peserta didik atau calon wali murid peserta didik tetap nyaman saat datang langsung ke sekolah SMK Al Hafidz., 


\section{VISA: Journal of Visions and Ideas \\ Vol 1 No 2 (2021) 78-100 E-ISSN 2809-2058 P-ISSN 2809-2643 \\ DOI: 47467/visa.v1i2.758}

hal ini di tegaskan kembali oleh Bapak Najmudin selaku Waka ur Hubin, beliau mengatakan bahwa:

"Walaupun kami telah gencar dan sosialisasi melalui media sosial dan membuka pendaftaran via website juga memfasilitasi calon peserta didik via website, tapi tetap saja kebanyakan calon peserta didik beserta calon wali murid datang langsung ke SMK Al Hafidz, tentunya dengan menggunakan protokol kesehatan juga. Tetapi pemasaran online melalui media sosial tetap kami nomer satukan".

Pelaksanaan di sini dijalankan sesuai dengan apa yang di rencanakan oleh sekolah yang pertama yaitu mengenai tim PPDB, waktu dan tempat, serta target yang dituju. Setiap saat dan setiap hari sekolah itu bisa mempromosikan sekolah akan tetapi waktu yang tepat yaitu pada waktu ajaran baru atau sebelum penerimaan peserta didik baru itu berlangsung sekitar bulan april sampai dengan waktu yang di tentukan oleh sekolah. Yang dilakukan tim PPDB SMK Al Hafidz Leuwiliang adalah bekerja sama dengan jenjang SMP/Mts terdekat untuk melakukan sosialisasi brosur dengan mengumpulkan wali murid kelas untuk mensosialisasikan brosur dan masalah PPDB, selain itu SMK Al Hafidz Leuwiliang ini mengutamakan daerah sekeliling lokasi tersebut karena mereka lebih tahu apa kelebihan dan kekurangan sekolah ini, yang kedua yaitu target yang di tuju, SMK Al Hafidz Leuwiliang ini tidak menargetkan siapa yang boleh atau tidak boleh menjadi pelanggan di SMK Al Hafidz Leuwiliang, SMK Al Hafidz Leuwiliang ini menyiapkan untuk semua golongan bisa masuk tidak memandang mana yang kaya dan mana yang miskin, dan yang ketiga yaitu tim pelaksana dalam memasarkan sekolah, semua yang ada dalam SMK Al Hafidz Leuwiliang tersebut berkewajiban untuk dapat mempromosikan sekolahnya agar masyarakat mengetahui dan mendaftarkan anaknya ke sekolah tersebut. Cara yang pertama kali dilakukan dalam pemasaran adalah scanning. Yaitu menganalisis kebutuhan yang diinginkan oleh masyarakat pada umumnya.

Dalam mempromosikan SMK Al Hafidz Leuwiliang sekolah ini juga menujukan program-program unggulan yang dimiliki SMK Al Hafidz Leuwiliang seperti:

\section{a.Simulasi Umroh}

Program ini diperuntukkan untuk semua kelas dan siswa. Prakteknya dilakukan perkelas dan mecontohkan tata cara tata cara umroh yang baik dan benar.

\section{b.Ekstrakulikuler}

Untuk ekstrakulikulernya di SMK Al Hafidz Leuwiliang ini memiliki 7 ekstrakulikuler yaitu: 


\section{VISA: Journal of Visions and Ideas \\ Vol 1 No 2 (2021) 78-100 E-ISSN 2809-2058 P-ISSN 2809-2643 \\ DOI: 47467/visa.v1i2.758}

1) Pramuka

2) Futsal

3) Rohis

4)Paskibra

5) Islamic Technology Active Community

6)Pencak Silat Tapak Suci

7)Futsal

Dengan bentuk-bentuk program seperti di atas di harapkan akan banyak yang tertarik untuk bersekolah di SMK Al HAfidz Leuwiliang, disela ketertarikan itu pihak SMK Al Hafidz Leuwiliang ini sambil menyampaikan bahwa SMK Al Hafidz bukan semata mata melakukan promosi lembaga secara kejuruan dan teknologi, tetapi juga sangat memperhatikan pelayanan untuk kehidupan beragama dan sosial yang harus saling membantu bekerja sama demi terciptanya kerukunan dan kemajuan SMK Al hafidz Leuwiliang.

Pelaksanaan yang dicapai dalam strategi pemasaran online sekolah adalah sebagai berikut:

Lulusan dari SMK Al Hafidz ini para peserta didik sudah sesuai dengan apa yang di harapkan pendidik terutama ada lulusan yang melanjutkan ke perguruan tingi Negri dan juga mendapatkan beasiswa, seperti yang dikatakan oleh bapak Najmudin selaku Waka Ur Hubin, mengatakan bahwa:

"Peserta didik lulusan SMK Al Hafidz Alhamdulillah ada juga yang diterima di perguruan negri teh, ada yang diterima di UNJ dan juga UIN Syarif Hidayatullah Jakarta. Jadi kami bukan hanya meyiapkan SDM untuk terampil kerja, jadi untuk melanjutkan pendidikan ke jenjang yang lebih tinggi juga bisa".

. Berbicara tentang biaya, jadi biaya yang ada di MTs. Mazra"atul Ulum ini cukup murah dibandingkan dengan SMK swasta lain yang ada dan program pembelajarannya pun hampir sama dengan pembelajaran yang ada disini, setiap wali murid harus mengeluarkan uang sekitar Rp 60.000 setiap bulannya untuk biaya SPP untuk tahun ajaran 2020/2021, dan untuk biaya SPP-nya setiap tahunnya itu berbeda kenaikan dalam setiap tahunnya itu sebesar Rp 5.000 kenaikan yang sangat sedikit jumlahnya, biaya kenaikan tersebut digunakan untuk penambahan tunjangan oleh pendidik yang ada, jadi semua golongan bisa masuk ke SMK Al Hafidz Leuwiliang tersebut tanpa adanya perbedaan antara golongan atas dan golongan bawah. 


\section{VISA: Journal of Visions and Ideas \\ Vol 1 No 2 (2021) 78-100 E-ISSN 2809-2058 P-ISSN 2809-2643 \\ DOI: 47467/visa.v1i2.758}

Bagi wali murid biaya tersebut di bilang murah sebanding dengan apa yang telah diberikan SMK Al Hafidz dalam poses pembelajaran. Dengan biaya yang cukup murah maka peserta didik pun selalu bertambah. SMK Al Hafidz merupakan madrasah yang strategis karena terletak di pinggir jalan raya yang berada di dekat peukiman desa dan mudah dijangkau oleh peserta didik yang jalan kaki maupun yang membawa kendaraan motor.

Dalam melakukan promosi pada masa pandemi covid 19 ini sekolah SMK Al Hafidz menggunakan media promosi online/ pemasaran online dan offline yaitu menggunakan media sosial juga brosur yang disebarkan di jalan-jalan bertujuan agar masyarakat mengenal dan mau menjadi konsumen di SMK Al Hafidz tersebut. Agar terlihat di jalan raya maka tim PPDB SMK Al Hafidz memasang spanduk dam banner di tiang pinggir jalan, spanduk ini juga di pasang didepan gerbang SMK Al Hafidzyang berisikan tentang program yang akan di capai untuk meningkatkan dalam pembelajaran.. Terkadang ada juga peserta didik yang mengetahui SMK Al Hafidz dari cerita teman dari mulut ke mulut biasanya ada tetangganya yang menyekolahkan anaknya ke SMK tersebut dan pelayanan yang ada di SMK Al Hafidz sangat baik dan memuaskan pelanggan.

Promosi seperti itu memberikan dampak positif bagi sekolah karena banyak yang mendaftarkan anaknya ke SMK. tersebut. Setiap tahunnya peserta didik yang mendaftarkan anaknya ke sekolah tersebut semakin bertambah walaupun dalam keadaan pandemi.

Tabel 4.3 Jumlah Peserta didik pasca pandemic covid 19

\begin{tabular}{|c|c|c|}
\hline No & Tahun Pelajaran & Jumlah Peserta didik \\
\hline 1. & $2020 / 2021$ & 160 peserta didik \\
\hline 2. & $2021 / 2022$ & 187 peserta didik \\
\hline
\end{tabular}

Peneliti juga mewawancarai dengan masyarakat sekitar. Ada yang menyampaikan bahwa beliau menyekolahkan anaknya di SMK Al Hafidz Leuwiliang adalah cerita dari tetangganya, menurut beliau (cerita tetangganya) beliau menceritakan bahwa sekolah SMK Al Hafidz ini mempunyai mutu dan teknologi yang bagus di tambah lagi dengan materi keagamaan yang diberikan setiap hari sehingga apa yang diterima anak anda nanti akan seimbang antara pendidikan umum dan pendidikan agama.

Adapula dari saudaranya, beliau pernah menyekolahkan anaknya beliau juga menceritakan pengalaman yang diperolehnya, SMK Al Hafidz ini tergolong baik..

Untuk tenaga pendidik yang ada di SMK Al Hafidz Leuwiliang ini aada yang sedang menempuh program Strata 1 (S1) atauun sudah S1, semua guru yang ada disini sudah sesuai dengan pengalaman mengajar. Maka dari itu bila promosi 


\section{VISA: Journal of Visions and Ideas \\ Vol 1 No 2 (2021) 78-100 E-ISSN 2809-2058 P-ISSN 2809-2643 \\ D0I: 47467/visa.v1i2.758}

dilakukan tim PPDB dengan membagi beberapa guru untuk datang ke sekolah mensosialisasikan brosur yang berisi kegiatan dan program yang akan dicapai SMK Al Hafidz Leuwiliang dengan cara mendatangi sekolah-sekolah SMP/Mts dengan membuat perjanjian terlebih dahulu kepada pihak sekolah untuk mensosialisasikan brosur di SMK Al Hafidz.

Akan tetapi pada pemasaran online ini, pihak sekolah SMK Al hafidz lebih mengoptimalkan lewat media sosial ataupun seringkali banyak calon peserta didik yang datang langsung ke SMK Al Hafidz Leuwiliang untuk mendaftarkan diri dan memngisi formulir. Walaupun begitu, formulir juga bisa diakses melalui website atau media sosial SMK Al Hafidz Leuwiliang.

Menurut peserta didik baru fasilitas-fasilitas yang ada sudah memenuhi kebutuhan peserta didik dalam rangka proses belajar mengajar dan dalam rangka memenuhi apa yang di inginkan oleh para peserta didik dalam belajar. Karena fasilitas dalam suatu sekolah sangat penting dalam kenyamanan peserta didik. Semua yang di rencanakan oleh kepala sekolahtelah dilaksanakan oleh tim PPDB dengan baik, manfaat yang bisa dipetik adalah ketika sekolah itu tampil dengan ciri khasnya yang menonjol maka diharapkan dapat menarik minat para stakeholder untuk menjadi konsumen tetap di sekolah tersebut, sehingga masa depan sekolah akan cerah dan mengalami perkembangan.

Dalam kaitannya dengan pemaparan diatas, maka tetap dibutuhkan berbagai upaya untuk meningkatkan mutu pelayanan pendidikan agar dapat bersaing dalam persaingan mutu lulusan dalam meningkatkan mutu pendidikan diantaranya:

1. Meningkat mutu pendidik

2. Meningkatkan kinerja guru

3. Meningkatkan kualitas peserta didik.

\section{Deskripsi Data Penelitian}

Penelitian ini membahas tentang Strategi Pemasaran Online yang dilakukan oleh SMK Al Hafidz dalam penerimaan peserta didik pada masa pandemi covid 19, khususnya pada tahun 2020 dan 2021. Metode pengumpulan data yang dilakukan dalam penelitian ini adalah wawancara, observasi, dan dokumentasi.

Berdasarkan paparan deskripsi data diatas, maka diproleh temuan penelitian sebagai berikut:

1. Strategi Pemasaran Online Pada Masa Pandemi Covid 19 dalam Penerimaan Peserta Didik

Strategi pemasaran online ini dilakukan sebelum kegiatan penerimaan peserta didik berlangsung, untuk itu dibutuhkan beberapa tahapan/ perencanaan strategi pemasaran online dan offline melaui beberapa tahap yaitu: 


\section{VISA: Journal of Visions and Ideas \\ Vol 1 No 2 (2021) 78-100 E-ISSN 2809-2058 P-ISSN 2809-2643 \\ DOI: 47467/visa.v1i2.758}

1) Pembentukan tim PPDB yang terdiri dari wali kelas dan pimpinan madrasah seperti waka kepeserta didikan, waka kurikulum, waka humas, dan waka sarpras

2) Menentukan perangkat pemasaran mulai dari waktu, tempat, dan target strategi pemasaran yang akan dilakukan

3) Menentukan media promosi ( saat ini lebih digencarkan pemasaran secara online ) melalui media sosial dalam kegiatan strategi pemasaran yang akan dilakukan

\section{Pengaruh Strategi Pemasaran Online pada masa pandei covid 19 dalam penerimaan peserta didik di SMK Al Hafidz Leuwiliang}

Pengaruh Strategi Pemasaran Online diatas dapat diuraikan bahwa: setelah peneliti melakukan penelitian, ternyata sistem pemasaran online tidak terlalu berpengaruh dalam penerimaan peserta didik. Strategi yang digunakan pun hamper sama dengan strategi yang dilakukan dalam sistem pemasaran offline. Dilihat dari jumlah peserta didik saat terjadi pandemi covid 19, peserta didik justru mengalami peningkatan.

Tabel 4.6 Hasil Penelitian Strategi Pemasaran Online pada masa pandemi Covid 19 Dalam Penerimaan Peserta Didik

\begin{tabular}{|l|l|l|}
\hline No. & Strategi Pemasaran Online & Pengaruh Strategi Pemasaran Online \\
\hline 1. & $\begin{array}{l}\text { Pembentukan tim PPDB yang terdiri } \\
\text { dari wali kelas dan pimpinan madrasah } \\
\text { seperti waka kepeserta didikan, waka } \\
\text { kurikulum, waka humas, dan waka } \\
\text { sarpras }\end{array}$ & Menarik minat calon peserta didik \\
\hline 2. & $\begin{array}{l}\text { Menentukan perangkat pemasaran } \\
\text { mulai dari waktu, tempat, dan target } \\
\text { strategi pemasaran yang akan } \\
\text { dilakukan }\end{array}$ & $\begin{array}{l}\text { menyesuaikan peluang pemasaran online pada } \\
\text { sekolah dan mengetahui sekolah mana saja yang } \\
\text { masih bersedia untuk dilakukan promosi }\end{array}$ \\
\hline 3. & $\begin{array}{l}\text { Menentukan alat atau media promosi } \\
\text { dalam kegiatan strategi pemasaran } \\
\text { yang akan dilakukan }\end{array}$ & $\begin{array}{l}\text { Penyebaran alat atau media promosi melalui } \\
\text { brosur, banner, pamflet, wali murid, media online } \\
\text { seperti facebook, instagram, dan story whatsapp. }\end{array}$ \\
\hline
\end{tabular}

Sesuai dengan hasil temuan peneliti terkait strategi pemasaran online pada masa pandemi covid 19 dalam penerimaan peserta didik, kemudian peneliti melakukan analisis hasil temuannya dengan dasar kajian-kajian teori dan fakta-fakta yang terdapat dilapangan, baik dari hasil wawancara, observasi, hingga dokumentasi yang telah dipaparkan pada bab sebelumnya. Dengan memadukan tiga teknik pengumpulan data (wawancara, observasi, dan dokumentasi), adapun fokus pembahasan dalam hal ini meliputi dua bahasan, yaitu: 


\section{VISA: Journal of Visions and Ideas \\ Vol 1 No 2 (2021) 78-100 E-ISSN 2809-2058 P-ISSN 2809-2643 \\ DOI: 47467/visa.v1i2.758}

\section{Strategi Pemasaran Online dalam Penerimaan Peserta Didik}

Dari hasil temuan penelitian yang ditemukan dilapangan, bahwa pada perencanaan strategi pemasaran dilaksanakan sudah berdasarkan proses yang baii secara keseluruhan. Yaitu mencakup dari strategi pemasaran hingga implementasinya untuk mencapai tujuan yang akan dicapai. Dengan adanya strategi yang telah ditetapkan diawal, sehingga dapat meminimalisir kegagalan atau problemproblem yang ditemui saat pelaksanaannya. Dalam hal ini strategi pemasaran yang dilakukan telah menetapkan beberapa perangkat pemasaran yang aka dilakukan setiap tahunnya.

Temuan yang pertama strategi pemasaran online dalam penerimaan peserta didik yang telah dipaparkan pada bab sebelumnya meliputi empat tahap, yaitu: a) Pembentukan tim PPDB, b) penentuan perangkat pemasaran, c) penentuan alat atau media promosi dalam strategi pemasaran, d) penentuan biaya SPP perbulan.

Kegiatan penerimaan peserta didik baru sudah berjalan dengan baik. Hal ini terbukti sesuai dengan tahapan-tahapan perencanaan yang disusun dengan acuan program kerja tahunan dari kepala sekolah, yaitu meliputi keberhasilan, langkahlangkah mencapai keberhasilan, penanggung jawab serta sumber dana yang diperoleh. Secara keseluruhan program pada penerimaan peserta didik baru ini tidak lepas dari kerjasama dan koordinasi dari pihak yang bersangkutan, dan dewan guru serta kepala madrasah.

Bapak Najmudin mengatakan dalam penerimaan peserta didik baru bertanggung jawab melakukan beberapa kegiatan seperti: perencanaan daya tampung calon peserta didik. Biasanya menjelang setiapawal tahun pelajaran dimana disitu merupakan waktu persiapan untuk pelaksanaan strategi pemasaran dalam peningkatan penerimaan peserta didik. Begitu halnyha, dengan strategi pemasaran online selama pandemic covid 19 ini. Semua dewan guru membantu dalam proses strategi pemasaran agar dapat berjalan dengan efektif.

SMK Al Hafidz ini merupakan Sekolah menengah Kejuruan yang di pandang berkualitas dan memiliki citra yang baik oleh masyarakat setempat, oleh kareanyan SMK Al Hafidz Leuwiliang ini memiliki strategi perencanaan yang baik.

Dalam marketing dikenal dengan sebutan STP pemasaran yaitu:

1. Segmentation

Yaitu tindakan konsumen tentang kebutuhan serta keinginan baik dimasa sekarang maupun dimasa yang akan datang. Segmentasi di gunakan untuk mengidentifikasi penetapan sasaran dari suatu perusahaan yang dapat dijalankan pada empat tingkat yaitu segmen, celah atau niche, wilayah lokal, dan individual.

Pertama segmen, menyadari bahwa pembeli berbeda-beda dalam keinginan, daya beli, lokasi geografis, perilaku pembelian. Jadi proses segmen dalam pemasaran 


\section{VISA: Journal of Visions and Ideas \\ Vol 1 No 2 (2021) 78-100 E-ISSN 2809-2058 P-ISSN 2809-2643 \\ DOI: 47467/visa.v1i2.758}

situasi dan kondisi calon konsumen adalah menjadi sorotan utama, dalam hal ini SMK Al Hafidz memiliki program pemasaran yang menyesuaikan dengan keadaan masyarakat setempat. Untuk semua golongan bisa membaca brosur-brosur yang disebarkan di jalan-jalan dan bisa membaca pamflet-pamflet, dan bisa juga lewat teman, dan omongan dari orang-orang.

Dalam tahap awal yang dilakukan oleh sekolah adalah survey, menganalisis dan merekap apa yang dibutuhkan dan diinginkan oleh masyarakat, sehingga sekolah dapat menyajikan produk yang sesuai dengan apa yang diinginkan. Tahap selanjutnya yaitu mengontrol secara berkala yang mana pembentukan program untuk selanjutnya, dalam artian, sekolah selalu update dengan perubahan sosial yang muncul serta apa yang dibutuhkan oleh masyarakat guna untuk memenuhi perkembangan zaman.

Kedua, yaitu segmentasi celah dimana dalam segmentasi ini bertugas untuk mengidentifikasi kelompok pasar dengan ciri yang berbeda. SMK Al hafidz dalam mengelompokkan konsumen berdasarkan latar belakang masing-masing bertujuan mengidentifikasi segala kebutuhan yang dibutuhkan oleh masyarakat.

Ketiga yaitu segmentasi yang mengarah pada keadaan wilayah dan lokal yaitu mengevaluasi atau meneliti keadaan wilayah, SMK Al Hafidz menyajikan lokal yang sesuai dengan kebutuhan pelanggan. Yang berada di pinggir jalan raya sehingga semua masyarakat mudah menjangkau dan mempermudah peserta didik jika membawa kendaraan.

\section{Targeting}

Targeting yaitu, pentargetan secara positif dalam menentukan daerah mana yang akan menjadi pelanggan SMK Al Hafidz . Di Prioritaskan tiga desa, yaitu desan Karacak, Karyasari dan Cibitung.

\section{Positioning}

Yaitu, tentang bagaimana menetapkan posisi untuk memperoleh keunggulan bersaing antar lembaga pendidikan yang ada di Kecamatan Leuwiliang, SMK Al Hafidz Leuwiliang ini sudah memiliki ciri khas tersendiri di banding dengan sekolah-sekolah lain seperti ekstrakulikuler yang berbasis agama danteknologi, hal ini sudah diakui oleh masyarakat dan dikenal masyarakat melalui ekstrakurikuler yang ada di SMK Al hafidz Leuwiliang .

Berdasarkan penjelasan diatas, intinya dalam sebuah strategi pemasaran yang terpenting adalah scanning atau identifikasi keadaan dan kebutuhan masyarakat sekitar agar masyarakat mendapat kepuasan yang diinginkan, ada sebuah teori yang menyebutkan bahwa perencanaan adalah "kegiatan yang akan dilakukan dimasa yang akan datang untuk mencapai tujuan". Maka dari itu suatu kegiatan yang dinilai baik pasti di awali dengan perencanaan yang matang, dan 


\section{VISA: Journal of Visions and Ideas \\ Vol 1 No 2 (2021) 78-100 E-ISSN 2809-2058 P-ISSN 2809-2643 \\ DOI: 47467/visa.v1i2.758}

apabila perencanaan itu matang maka hasil yang di dapat juga baik dan sesuai dengan tujuan yang ditetapkan.

\section{Pengaruh Strategi Pemasaran Online Dalam Penerimaan Peserta Didik Pada Masa Pandei Covid di SMK Al Hafidz Leuwiliang}

Implementasi dari strategi pemasaran online tidak terlalu berpengaruh terhadap penerimaan peserta didik. Karena pemasaran secara offline pun masih perlu dibutuhkan oleh pihak pelanggan (calon peserta didik). Dalam rangka mempertahankan eksistensi keberadaan sekolah di mata publik, prioritas utama dalam pembentukan dan pelestarian adalah menampilkan suasana lembaga yang aktif, bersih, rapi, disiplin, dan berakhlak baik.

\section{KESIMPULAN DAN SARAN}

\section{Kesimpulan}

Berdasarkan hasil penelitian pada BAB IV, maka dalam penelitian ini dapat disimpulkan sebagai berikut :

1) Dalam strategi pemasaran online di SMK Al Hafidz Leuwiliang dilaksanakan oleh setiap elemen di sekolah, hal ini dikarenakan agar perencanaan strategi pemasaran yang dilaksanakan akan dapat berjalan lebih efektif dan maksimal. Dalam strategi pemasaran online, tahapan yang dibuat yaitu: Pembentukan tim PPDB yang terdiri dari wali kelas dan pimpinan madrasah seperti waka kesiswaan, waka kurikulum, waka humas, dan waka sarpras, menentukan perangkat pemasaran mulai dari waktu, tempat, dan target strategi pemasaran yang akan dilakukan, menentukan alat atau media promosi dalam kegiatan strategi pemasaran yang akan dilakukan, dan menentukan biaya SPP per bulan yang terjangkau agar semua kalangan bisa masuk ke madrasah tersebut. SMK Al Hafidz juga mengunakan tiga tahapan strategi pemasaran online yaitu : Segmentation ; Yaitu tindakan konsumen tentang kebutuhan serta keinginan baik dimasa sekarang maupun dimasa yang akan datang, Targeting ; yaitu pentargetan secara positif dalam menentukan daerah mana yang akan menjadi pelanggan SMK Al Hafidz . Di Prioritaskan tiga desa, yaitu desan Karacak, Karyasari dan Cibitung, dan juga Positioning; yaitu tentang bagaimana menetapkan posisi untuk memperoleh keunggulan bersaing antar lembaga pendidikan yang ada di Kecamatan Leuwiliang.

2) Implementasi dari strategi pemasaran online tidak terlalu berpengaruh terhadap penerimaan peserta didik. Karena pemasaran secara offline pun masih perlu dibutuhkan oleh pihak pelanggan (calon peserta didik).

\subsection{Saran}

Tanpa mengurangi rasa hormat kepada semua pihak dan demi suksesnya kegiatan strategi pemasaran di SMK Al Hafidz Leuwiliang agar berjalan dengan lebih 


\section{VISA: Journal of Visions and Ideas \\ Vol 1 No 2 (2021) 78-100 E-ISSN 2809-2058 P-ISSN 2809-2643 \\ DOI: 47467/visa.v1i2.758}

lancar dan memperoleh hasil yang maksimal, maka penulis memberikan saran, antara lain:

1) Kepada sekolah, pendidikan untuk selalu bekerja lebih giat dan memperhatikan masyarakat sekitar agar lebih mengetahu cara bagaimana mendaftar melalui media sosial utuk melahirkan SDM yang berkualitas dengan selalu melaksanakan kegiatankegiatan dengan baik, serta meningkatkan dan memperdayakan seluruh sumber daya yang ada demi memperbaiki dan meningkatkan mutu pendidikan islam utnuk mencapai kepuasan pelanggan.

2) Kepada akademisi, diharapkan kepada akademisi yang akan melaksanakan penelitian mengenai strategi pemasaran onlinedalam peningkatan penerimaan peserta didik, dapat lebih mengembangkan kajian-kajian yang sudah ada mengenai kegiatan strategi pemasaran yang ada dan kegiatan penerimaan peserta didik.

3) Kepada peneliti, diharapkan peneliti dapat memperhatikan proses yang telah terlaksana dalam tahapan strategi pemasaran online, sehingga peneliti dapat mengimplikasikannya ketika ingin berada di lingkungan sekolah kelak.

\section{DAFTAR PUSTAKA}

Buna"l, 2008. Penelitian Kualitatif, Malang: Perdana Offset

David ,Wijaya. 2012, Pemasara Jasa Pendidikan, Jakarta : Salemba Empat

Fitria, Suhailah . 2018. Strategi Pemasaran Jasa Pendidikan Di Sekolah Dasar Islam Terpadu Diniyah Al-Azhar. Jambi

Hardiningrum, Andini. 2018. Strategi PPDB Pada Masa Pandemi Covid 19 Di TK Khadijah Pandegling Surabaya. Surabaya : Universitas Nahdatul Ulama

Huda, Nurul. 2017, Pemasaran Syariah : Teori dan Aplikasi. Bandung : Kencana

Ikhsan, Bayanullah. 2018, Marketing Syariah. Jakarta : Gramedia

Kamus Besar Bahasa Indonesia, 2002.

Kotler, Philip. 2017,Manajemen Pemasaran : Analisis, Perencanaan, Implementasi dan Pengendalian. Jakarta : Erlangga

Mathew B. Miles dan A. Michael Huberman, 1992. Qualitative Data Analysis, terjemahan Jetjep Rohendi Rohidi, Jakarta : UI Press

Nisa, Khoirun. 2018. Strategi Pemasaran Online Dan Offline, Surabaya : Universitas 17 Agustus 1945

Sugiono, 2017. Metode Penelitian Pendekatan Kuantitatif, Kualitatif, dan R \& D. Bandung : Alfabet

www.taupasar.com 